Marina Protrka Štimec

Sveučilište u Zagrebu

mprotrka@ffzg.hr

ORCID: 0000-0002-3764-5625

Mirela Dakić

Sveučilište u Zagrebu

mireladakic1@gmail.com

ORCID: 0000-0002-1117-2145
Data przesłania tekstu do redakcji: 10.01.2019

Data przyjęcia tekstu do druku: 19.02.2019

\title{
„Tijelo pamćenja je pčela koja me bode.“ Emancipatorne prakse ženskog pisma 80-ih*
}

\begin{abstract}
Protrka Štimec Marina, Dakić Mirela, „Tijelo pamćenja je pčela koja me bode.“ Emancipatorne prakse ženskog pisma 80-ih ("The body of recollection is a bee which stings me." Emancipatory practices of women's writing in Croatian literature of the 1980's). "Poznańskie Studia Slawistyczne" 16. Poznań 2019. Publishing House of the Poznań Society for the Advancement of the Arts and Sciences, Adam Mickiewicz University, pp. 243-255. ISSN 2084-3011.
\end{abstract}

The book of essays Smrtni grijesi feminizma (The Deadly Sins of Feminism), written by Slavenka Drakulić, and Irena Vrkljan's novel Svila, škare (The Silk, the Shears), both published in 1984, became the samples of feminist activism and the poetics of l'écriture féminine in Croatian literature. Considering their generic aspects and their narrative strategies focused on revealing the conflict between public/historical/political and personal/everyday/trivial, in our paper we will discuss Vrkljan's novel as outstanding example of the emancipatory changes in the cultural field of the 1980's. "Trivial as political" in Slavenka Drakulić's writing, articulated through Irena Vrkljan's autobiographical narrative, incites the emancipatory power of l'écriture féminine that simultaneously reflects the Other in itself, produces its own difference and writes without inscribing itself. This type of women's writing, as previously defined by Hélène Cixous, is presented in Irena Vrkljan's text as writing its own life that is "always in-between" and that undermines declared democratic values as much as the politics of literature, as understood by Jacques Rancière. Revealing discordances between poetic and social hierarchies, women's writing makes changes in the partition of the visible and the sayable, in the intertwining of being and writing, body and words.

Keywords: The Deadly Sins of Feminism; Slavenka Drakulić; The Silk, the Shears; Irena Vrkljan; women's writing; politics of literature

* Ovaj rad je sufinancirala Hrvatska zaklada za znanost projektom IP-2018-01-7020 „Književne revolucije“. 


\section{Uvod}

Kulturno polje u Hrvatskoj 80-ih godina obilježeno je značajnim stupanjem autorica i feminističkih tema na književnu scenu. Prema njihovoj prisutnosti u domaćoj kritičkoj recepciji, možemo zaključiti da je riječ o jednoj od dominantnih tendencija toga desetljeća, tim više što je vidljivost autorica od sredine 80 -ih pojačana paradigmatskim pripisivanjem pojma ženskoga pisma njihovim književnim tekstovima. Iako se otada u nišu ženskoga pisma u književnokritičkim, a zatim i povijesnim prikazima svrstava cjelokupna književna produkcija autorica 80-ih i nadalje, namjera je ovoga rada ustanoviti distinkciju između feminističkoga angažmana književnoga teksta uopće te specifičnoga feminističkog potencijala određenih narativnih strategija - sukladno teorijskim implikacijama pojma ženskoga pisma koji je 70-ih godina u domenu feminističke književne kritike uvela Hélène Cixous. Rad će stoga ponuditi uvid u kulturološki i književnopovijesni kontekst koji je 80-ih godina 20. stoljeća omogućio pojavu i afirmaciju ženskoga pisma - imajući u prvom redu pred sobom narativne strategije romana koji je proglašen rodonačelnikom žanra - Svila, škare (1984) Irene Vrkljan. Razmatranjem odabranoga književnog teksta kao specifičnog prostora za artikulaciju osobnoga kao političkoga povezat ćemo pitanje njegova feminističkog angažmana sa širim shvaćanjem književnosti kao inherentno politične - kako je to odredio Jacques Rancière, s potencijalom koji ne proizlazi iz politike autora ili mogućnosti predstavljanja identiteta (Rancière, 2008, 7), već iz sposobnosti teksta da „na scenu zajedničkog uvodi nove objekte i subjekte“ te tako sudjeluje u (pre)raspodjeli ,prostora i vremena, mjesta i identiteta, govora i buke, vidljivog i nevidljivog“ (Rancière, 2008, 8).

Među najvidljivijim aspektima književne produkcije autorica 80 -ih je onaj izravno angažirani i aktivistički - reprezentativni su primjeri takve prakse eseji Slavenke Drakulić objavljivani od kraja 70-ih godina u nizu časopisa i novina (Polet, Književna reč, Start, Duga, NIN, Vjesnik, Danas). Njihov je izbor objavljen 1984. godine u zbirci simptomatičnoga naslova - Smrtni grijesi feminizma koji s ironijskim odmakom upućuje na javni i politički stav prema feminističkoj kritici sustava koji se smatrao rodno egalitarnim. Izravna artikulacija kritičkoga stava, dijalogičnost, polemičnost, ironija i humor u spomenutim esejima mogu se čitati kao simptom 
promjena sustava vrijednosti koje su, uvelike pod utjecajem zapadnih feminističkih strujanja, zahvatile tadašnje jugoslavensko društvo. Iako korespondiraju s vremenom nastanka, čitani s odmakom od tridesetak godina, oni razotkrivaju duboku ukorijenjenost patrijarhalnih vrijednosti protiv kojih nastupaju te su i danas aktualni u načinu na koji se dotiču pitanja seksualnosti, prava žena, predodžbi vezanih za brak, reprezentacije rodnih uloga i komodifikacije koja ih prožima.

Drakulić u eseju po kojem je zbirka naslovljena - Smrtni grijesi feminizma - upućuje na nedostatak političkoga prostora za artikulaciju specifičnih ženskih tema i pitanja, nesvodivih pod postojeći politički okvir. Štoviše, autorica dovodi u vezu rastući antifeminizam i seksizam s rasplamsavanjem nacionalizma, čija će sprega eskalirati nekoliko godina kasnije u Globusovu sramotnom napadu na „vještice iz Rija“. Pruživši uvid $\mathrm{u}$ antifeminističke argumente, referirajući se najprije na institucionalni kontekst Konferencije za aktivnost i ulogu žena u društvenom razvoju Jugoslavije na kojoj su domaće feminističke tendencije proglašene uvezenima iz zapadnih zemalja te bi kao takve trebale biti suzbijene i eliminirane (Drakulić, 1984, 102), autorica ih sagledava kao simptome općega stava prema feminizmu.

U tome kontekstu kultura postaje potencijalno poprište otpora i otvaranja ženskoga pitanja. Referirajući se na tu ulogu, posebice u eseju Zašto žene vole bajke?, Drakulić problematizira reprodukciju stereotipnih rodnih odnosa u trivijalnoj literaturi - „herz-romanima“, „'romantičnoj” štampi“ (Drakulić, 1984, 32) - te apostrofira potencijal književnosti za kritiku postojećega stanja.

U ocrtanoj političkoj i kulturnoj klimi 80-ih sve istaknutija pojava autorica koje sa specifičnim kritičkim impulsom progovaraju o ženskim pitanjima prepoznata je u domaćoj kritičkoj recepciji kao svojevrstan pokret koji se od objavljivanja romana Svila, škare Irene Vrkljan 1984. - iste godine kada je objavljena i zbirka Slavenke Drakulić - prepoznaje kao žensko pismo, preuzimajući pojam iz francuske feminističke kritike 70-ih, ponajprije iz tekstova Hélène Cixous. Iako njegovu primjenu možemo kritički sagledati kao specifičan odgovor na zahtjev za otvaranjem i revalorizacijom književnoga kanona i povijesti postavljen iz feminističke perspektive, kako bismo izbjegli pretvaranju ženskoga pisma u ladicu u koju se smještaju tekstovi određenih autorica, u nastavku ćemo ukratko ukazati na njegove teorijske 
implikacije te ih primijeniti na čitanje već spomenutog rodonačelnika žanra u hrvatskoj književnosti - romana Svila, škare Irene Vrkljan.

Za razliku od angloameričke feminističke kritike koja je svoj ponajprije „sadržajni“ interes usmjerila na pitanje književne reprezentacije, odnosno na „slike žene“ u „muškoj prozi“ i tematizaciju ženskoga iskustva u ,ženskoj prozi“ (Biti, 2000, 120 v. feministička kritika), francuska feministička kritika radikalnije se usmjerava na razinu teksta - podrivajući odatle reprezentaciju samu. Tako je za Cixous pisanje uvijek obilježeno, upisivanjem ženskosti ili muškosti - određene libidne, kulturne i političke ekonomije (Cixous, 2012, 245), no to obilježje ne korespondira sa spolom autora, već, kako je to istaknula Toril Moi - sa spolom pisanja (Moi, 2007, 153). Prema Cixous, žensko je pismo blisko pjesništvu, nesvjesnom, kulturno potisnutom, majci, majčinu mlijeku - to je pisanje „bijelom tintom“ (Cixous, 2012, 246-247) koje najavljuje „mogućnost promjene“ i ,transformacije društvenih i kulturnih struktura" (Cixous, 2012, 245). Kako to objašnjavaju Čale Feldman i Tomljenović, žensko pismo pri tom „ne treba shvatiti kao drugu vrstu jezika [...] jer on pripada istim vodama i sadrži iste tvari kao i maskulini diskurs, samo teče protiv njegove struje“ (Čale Feldman, Tomljenović, 2012, 68).

Iako se pojmom ženskoga pisma naglaskom na tekstu nastoji izbjeći opreka ,ženske“ i „muške“ književnosti, za domaću je recepciju pojma od njegova uvođenja u tematskome broju časopisa Republika iz 1983. godine ipak specifično da se veže za tekstove određenih tematskih i/ili stilskih obilježja koje potpisuju isključivo žene. Interpretacija koja žensko pismo utemeljuje u spolu autora ponuđena je u najutjecajnijem tekstu temata „Ženska književnost“ $i$,„žensko pismo “ Ingrid Šafranek. Prema Šafranek, žensko pismo možemo pripisati tekstovima ,u kojima su autorice više ili manje svjesne svoje - i to ne samo spolne - specifičnosti, gdje one doista upisuju vlastitu različitost i to ne samo na tematskoj, nego i na tekstualnoj razini, te nastoje oivičiti svoju poziciju žene-subjekta-koji-piše“ (Šafranek, 1983, 7; istaknule M.P.Š. i M.D.). Međutim, interpretacija ženskoga pisma koja polazi od spola autora nije sasvim u skladu s izvornim značenjem pojma kako ga koncipira Cixous.

Ako, slijedeći Cixous, žensko pismo shvaćamo kao emancipacijski potencijal tekstualnosti, tada se ono ne pokazuje kao aspekt teksta esencijalno povezan sa spolom biografskoga autora, već isključivo kao modus čitanja 
i interpretacije - shvaćanje koje nedostaje njegovim primjenama u recepciji autorica od prvih tekstova objavljenih 80-ih naovamo. Unatoč teorijski osvještenijem pristupu u Republici, pojam se od prve književnokritičke primjene u kritici romana Svila, škare Velimira Viskovića naslovljenoj Žensko pismo (Visković, 1988, 250-252) autoricama pripisuje prema nejasno razlučenim kriterijima biografije i tematskih i stilskih aspekata teksta kao polazišta interpretacije. U nastavku ćemo usmjeriti pozornost na emancipacijske strategije prepoznatljive u romanu Svila, škare Irene Vrkljan: na narativne strategije koje koristi, kao i na tretman jezika i pisanja iz kojih proizlaze koncepti pamćenja i sjećanja i mogućnosti interpretacije na koje ćemo uputiti povezujući ih $\mathrm{s}$ autoričinom poezijom nastalom u ranijim fazama njezina stvaralaštva, kada piše u okviru „nadrealističke grupacije“ (Milanja, 2000, 169). Postupci koje koristi mogu se interpretirati kao emancipacijski potencijal ženskog pisma ukoliko njima iskušava i propituje dominantni konsenzus oko zajednički važnih tema, osvjetljavajući ono što je zanijekano ili prešućeno. U javnom prostoru, kako je pokazao Yannis Stavrakakis $(2012,554)$, umjetnost intervenira na različite i međusobno suprotstavljene načine, hegemonijske i protuhegemonijske. Nas će zanimati u kojoj se mjeri političnost romana Irene Vrkljan može sagledavati u kontekstu emancipacijskih praksi nastalih u kontekstu ženskog stvaralaštva 80-ih godina 20. stoljeća koje su istovremeno utjecale na promjene u društvenoj, kulturnoj i umjetničkoj sferi - preoblikujući kulturno polje i pripadajuće umjetničke prakse.

\section{Svila, škare: emancipacijski potencijal teksta}

Gledajući u cjelini, roman Svila, škare istovremeno angažira barem tri razine na kojima se razotkriva rodno/spolno kodiranje jezika, praksi, identiteta i sjećanja koja postaju uporište emancipatornog angažmana teksta.

\subsection{Izravno tematiziranje ženskog identiteta $i$ iskustva}

Ovdje je riječ o prepoznatljivom aspektu romana koji je usmjerio dosadašnje razumijevanje i interpretaciju ženskog pisma kao tematiziranja „specifičnog ženskog iskustva“ u okvirima patrijarhalne obitelji, 
građanskog društva i opće povijesti 20. stoljeća. U romanu se taj aspekt pisanja naziva „sumornim krajolikom za žene“ (Vrkljan, 1984, 53).

Sumoran krajolik za žene, ta hrvatska nizina pod Sljemenom, pod planinom koja klizi, koja se trese i izaziva strahove. Muškarci sjede pod „Starim krovovima“ i jedu janjetinu, piju mutno bijelo vino, žene su tegleće mazge, majke i nakon kratkog vremena umorne ljubavnice (Vrkljan, 1984, 53).

Krajolik, odnosno slika prostora i ovdje će, kao i na drugim mjestima u romanu, ali i ranije u poeziji, označiti prevrednovanje jedne dimenzije upućivanjem na promjene koje se događaju unutar druge. Ovdje konkretno promjena je vidljiva u stagnaciji i propadanju koji se događaju „nakon kratkog vremena“ u kojem se ,ženski život“ pripovijeda kroz fragmente slika i sjećanja: bilo da je riječ o poznatim ili nepoznatim ženama. Vrijeme i prostor pri tom se međusobno pretapaju kako bi slike, siluete i procesi bili vidljiviji i neumitniji:

Kakav bijaše taj naš ženski život u Zagrebu? Vidim žene s teškim taškama na ulici, vidim kako se smiju i puše po kavanama, vidim bake s unucima po parkovima, kćerke su u uredu ili u tvornici, vidim malu gospođu K. u svom vječnom kućnom ogrtaču koja je u grad došla iz siromašnih predjela krša, došla u našu kuću u prizemni stan i koja je svakom govorila: dušo, dušo moja (Vrkljan, 1984, 122).

Roman time opisuje i iznevjerava konture osobne priče u kojoj se brojni likovi žena međusobno ogledaju u kaleidoskopu međusobno sumjerljivih jezika i povijesti. To su ,jedna glumica spremna na bijeg s nekim Francuzom“ (Vrkljan, 1984, 124), „Ankica, seljačko dijete iz Metkovića“ (Vrkljan, 1984, 125), Elika koja kuha juhe (Vrkljan, 1984, 101), mama, baka, Melita, pa onda i pripovjedačica sama i njezine sestre. Birajući intimne fragmente, Vrkljan izostavlja mogućnost koherentne biografije, pribjegava naraciji u kojoj je osobno istodobno unutarnje tjelesno i intimno, ali i prepoznatljivo i primjenjivo na sve. Ono je time - izazivajući i jasno komentirajući povijesne i političke promjene s ruba iskazivog - kroz svijest djeteta, djevojke ili odrasle žene - na više razina političko. Zato i umetnuti pasusi - Verine priče i Nadina svjedočanstva - funkcioniraju i kao referencijalne točke i kao prepoznatljiva mjesta „trivijalnog života žena“, kako ih naziva Slavenka Drakulić, upućujući na krilaticu drugog vala feminizma: Trivijalno je političko. Verino pismo apostrofira upravo taj aspekt osobnog i anonimnog sudjelovanja ,jednog života“" u cjelini zajednice: 
vraćam ti natrag rukopis tvoje knjige o nama. Nakon našeg telefonskog razgovora sjela sam za šivaći stroj, stavila na njega pisaću mašinu i također počela pisati. Nisam kuhala, nisam spremala stan, samo sam pisala. Šaljem ti moje priče iako mi se sve čini isuviše privatnim jer nedostaje društvo, čak i obitelj. Ti me drugačije spominješ i to je mnogo za jedan život koji nije ništa značajno učinio za zajednicu. Nemoj me shvatiti krivo: iako se nadam da ne pripadam bezličnoj masi, ipak sam na neki način njen dio... S moje četiri priče učini što želiš... Vera (Vrkljan, 1984, 57, istaknule M.P.Š. i M.D.).

\subsection{Forma pripovijedanja: autobiografski diskurs}

Drugu razinu čini pripovijedanje osobnog života i „rastresita“ rodno kodirana struktura romana koje su u kritici i književnoj povijesti prepoznate kao „ženske“ (Nemec, 2003, 345-346), odnosno sociološki omogućene stečevinama feminizma (Milanja, 1996, 120). Tako Julijana Matanović ističe da ova knjiga

pokazuje gotovo sve karakteristike suvremene autobiografije. Tematski je određena trenutkom samospoznaje. Započinje s najudaljenijom točkom pamćenja. Središnji događaji, kao polazišta brojnih kolažnih refleksija, mogli bi se ulančati u kronologijski slijed, cjelovita priča o Ja dobiva se slaganjem iz odnosa Ja prema drugima. Epizode su oblikovane u formi priče i iz njih se iščitava razvoj osobnosti i karaktera. Život pojedinca i njegova mala, osobna povijest stavljeni su iznad velike povijesti, a velika je povijest upisana u tekst da bi se predočila poznata vremenska shema i da bi se proučile posljedice moćnih odluka (Matanović, Vrkljan, 2004).

Osim navedenog, autobiografskom okviru u prilog svakako ide eksplicitna podudarnost imena autorice, pripovjedačice i glavnog lika romana. Kao ogledni primjer tzv. autobiografskog ugovora (Nemec, 2003, 345-346) ovaj roman svoju reprezentativnost može zahvaliti referencama iz kojih čitatelji/ce rekonstruiraju linearnu povijest, npr. u uvodnim stranicama, svojevrsnom rezimeu i motu romana:

Moja majka sjedi u jednoj sobi na 4. katu u Zagrebu i ne može izreći svoju tjeskobu. Moje sestre borave udaljene jedna od druge u svojim kuhinjama. Oko njih viču djeca, vriju juhe na štednjacima. U Homburgu, u Palmotićevoj. Partizan V. je mrtav, bosanske su planine napuštene. Moj otac leži na Mirogoju, polje devetnaest, grob broj četiri. Jedan slikar, prijatelj iz provincije, nije našao svoje iskupljenje.

Trinaest godina boravka u Zapadnom Berlinu. Moji prijatelji u Charlottenburgu, u Steglitzu. Claudio me hrabrio, Benno je napravio mjesta na svom pisaćem stolu. 
Virginia Woolf. Charlotte Salomon. Žene, koje žele uteći iz djetinjstva. Proziv lažne poniznosti. Za srdžbu. I za sjećanje (Vrkljan, 1984, 5).

Ovdje valja napomenuti da se tekst ne samo svojom fragmentarnošću, nego i načinom narativne organizacije dosljedno izmiče tako shvaćanoj žanrovskoj pripadnosti. Naime, roman pulsira između vlastite izvanjske strukture i unutarnjih narativnih mehanizama koji je opovrgavaju. Izvanjska struktura romana slijedi načelo kronologije i linearnosti - od Djetinjstva u kraljevini, poglavlja u kojem je riječ o najranijim godinama, preko Drugih vremena fokusiranih na poslijeratne godine i književne početke, do Kretanja vremenski najbližih trenutku pripovijedanja. Istovremeno se unutar pojedinih dijelova taj princip linearnosti dosljedno iznevjerava različitim strategijama: razotkrivanjem perspektive pripovjedne instance, narušavanjem vremenskoga slijeda reminiscencijama na prošlost ili pripovijedanjem o budućnosti, zatim upućivanjem na višeslojne izvore poput obiteljskih uspomena, stvari, fotografija, priča koje su ispričali drugi, npr. onih koje su se dogodile u obitelji ili u ranom djetinjstvu. Tu su i umetnuti tekstovi poput spomenutog Verina pisma i Nadinih priča koji umnožavaju perspektive pripovijedanja, zatim List iz dnevnika koji je dodan na kraju knjige i koji je kao i ovi drugi umetnuti dijelovi romana pisan kurzivom. U svakom od ovih primjera ponavlja se sličan postupak: linearna naracija u kojoj se pripovijeda fragment djetinjstva ili obiteljske/opće povijesti u jednom trenutku se, asocijativnom logikom, spaja s manje ili više srodnom ili analognom slikom ili fragmentom, što dovodi do pojačavanja dojma i proizvodnje novog ili naglašenog značenja koje se u sljedećem koraku napušta uvođenjem novog stupnja autoreferencijalne jezične igre koja ostavlja polje referencijalne semantike. Tako se npr. u prvom poglavlju (Žica) pripovijeda o granicama koje su Ireninu svijetu djetinjstva postavljali roditelji: to je dvorište, a ne Cigani koji peku kukuruze, otmjena Lotte, a ne tamnoputa kućepaziteljeva kći Gordana, da bi se niz dovršio slikom boravka u stranom prostoru drugog grada, u posjeti maminoj prijateljici čija djeca love leptire i pribadaju ih iglama, što djevojčicu ispunjava patnjom, a njezine nove znance zabavlja.

Očajno sam molila majku koja je sjedila u bijeloj vrtnoj stolici da otputujemo kući. Djeca anđela su se smijala, smijala se i majka. Uvijek nas lošem uči onaj koji tašto misli da sve najbolje zna. I ja sam shvatila da stati na pola puta znači isto što i ići do kraja. 
Moramo se čuvati početaka. Otada me fini smeđi prah uvijek podsjeća na iglu, koja potom slijedi (Vrkljan, 1984, 12).

Tim se postupcima istovremeno ispisuju konture teksta koji se čita kao autobiografija, koja je refleksivna i narativna i koja se u tom izgrađivanju istodobno opovrgava, dovodi u pitanje - pokazujući da je ,pripovijedanje vlastitog života“" istovremeno i forma i središnja tema romana Svila, škare.

\subsection{Unutarnja emancipacija teksta - jezik}

Treći emancipatorni aspekt romana povezan je s načinom na koji se jezični potencijal ovog proznog teksta povezuje s onim koji je Irena Vrkljan razvijala u ranijim fazama svog stvaralaštva - u pjesničkim zbirkama Krik je samo tišina (1954), Soba, taj strašan vrt (1966) i U koži moje sestre (1982). Ovu posljednju zbirku Milanja (2000, 175) eksplicite dovodi u vezu s romanom Svila, škare, smatrajući da u ovoj kasnijoj fazi autorica indicira drukčiju ideju pjesništva, uvodeći subjektivne, ,intimno-privatne“, ,autobiografski određene“ elemente. Mi bismo ovdje, nasuprot tome, uputili na one aspekte romana koji upućuju na transgresiju slika, motiva i postupaka iz pjesničkih zbirki. Time bismo iznova aktualizirali pitanje koje je u spomenutom broju Republike, unatoč načelnom povezivanju ženskog pisma sa spolom autora, postavila Ingrid Šafranek, a tiče se nerazlučivosti poetičkih i političkih učinaka ženskog pisma i avangarde (Šafranek, 1983, 19, 22). Prema Šafranek, žensko je pismo u konačnici „ono što se zbiva na razini stila“ (Šafranek, 1983, 15), prema stilskom kriteriju i u najkraćem smislu - avangardno (Šafranek, 1983, 22-23). Karakterizira ga „prezir prema kompoziciji“, u korist fragmenta, patchworka i nekoherentnosti, ,zanemarivanje označenog, dakle zanemarivanje tematskog, referencijalnog, čak prividna odustnost događajnosti u romanu - a za volju jake semantizacije označitelja“, odnosno ,prodor pjesništva u prozu“ (Šafranek, 1983, 11). U kontekstu dosadašnjih primjena pojma ženskog pisma na roman Svila, škare, ali i na kasniju prozu Irene Vrkljan, taj bi uvid mogao predstavljati polazište za njegovo preoznačavanje, s obzirom na to da opetovano isticanje srodnosti između autoričine poezije i proze nije dovedeno u vezu s teorijskim implikacijama pojma. Primjerice, stavljajući 
naglasak u izdanjima autoričine proze na odnos s njezinom poezijom, Andrea Zlatar primjećuje da se već u zbirci Soba, taj strašan vrt oblikuje „lirski subjekt u prvom licu jednine, refleksivan, sklon nizanju slika, gotovo nabrajanju, otvoren prema miješanju lirskoga i pripovjednoga“" (Zlatar, 2006, 7) te da Svila, škare transponira autoričine opsesivne temate ,iz lirskog i pjesničkog u prozno i pripovjedno“ (Zlatar, 2006, 10), štoviše, da je njezino pripovijedanje u prozi ,izraslo iz ranije poezije“ (Zlatar, 2008, 113), a suočeno s neprijelaznim pragom iskazivanja iznova se „povlači i prepušta mjesto pjesničkom jeziku slika i lirskim izričajima, osjećajima istrgnutim iz kontinuiteta pripovjednog doživljavanja“ (Zlatar, 2004, 13). No koji je razlog pripisivanju pojma ženskoga pisma autoričinoj prozi, ali ne i poeziji? Nije li, prema Cixous, upravo pjesništvo krajnja manifestacija ženskoga pisma? Kakve bi implikacije takav potez imao na postojeću primjenu pojma, od opusa Irene Vrkljan nadalje?

U Svili, škare se na nekoliko razina narativne organizacije teksta vidi kako se referencijalno polje - opisivanje konkretnog događaja, situacije, povijesnih zbivanja - rastače i izokreće prema autoreferencijalnosti, prema samom polju jezika i mogućnosti iskazivanja svojstvenog pjesništvu. Tako se u prvom dijelu romana ističe: „Unutarnji svijet ladica i ormara pamti se bolje nego glatki, vanjski oblik koji je prevelik, koji se ne može obuhvatiti, srediti ili uzeti u ruke - dok one brojne sitnice jasno ostaju pred očima i nezaboravne su“" (Vrkljan, 1984, 97).

Analogno, u pjesmi Soba, taj strašan vrt prostor sobe postaje fantazmagoričnim ili u određenom smislu heterotopijskim prostorom koji, jasno izdvojen, ograničen zidovima, čuva „strah, [...] malene stvari od stakla [...] razbijen,/strašan taj vrt unutar zida od sirove žbuke/ili bijelog kreča, svejedno“ (Vrkljan, 1966, 9). Soba otkucava neko drugo vrijeme; ona je izdvojeno mjesto u kojem supostoje različite razine realnosti, ona je „tako očajna, lijepa, tako strašna,/kolijevka, grobnica, postelja“, soba „moje mašte, mog djetinjstva i pepela“ (Vrkljan, 1966, 10).

Tendencija proznoga iskaza k pjesničkome, unutar narativnog okvira koji se poigrava svojom temom i formom - pripovijedanjem vlastitog života, u romanu uspostavlja sukladnu koncepciju pamćenja, odnosno ,tijela pamćenja“, semantizirajući tako i metonimijsku vezu s osobnim, intimnim, utjelovljenim, i metaforičku vezu s jezikom, zajednicom, preraspodjelom prostora, vremena, identiteta i (ne)vidljivog. Tijelo i pamćenje supostoje 
i u naslovnoj sintagmi romana i citatu iz teksta koji se na makrorazini vezuje uz majku: jezik, identitet i stvaranje. U završnom poglavlju, a prije svojevrsnog epiloga, prepoznatljivom strategijom Vrkljan iskaz premješta u autoreferencijalno polje, tvrdnjom: „Jezik je domovina tamo gdje stojimo, a kruh je njeno podne“ (Vrkljan, 1984, 139). Analogija između škara koje ranjavaju svilu djetinjstva i olovke koja „grebe, ranjava papir“ (Vrkljan, 1984, 140) uspostavlja svojevrsnu analogiju između pisanja i življenja, odnosno iscjeljivanja i traume, pri čemu se izmjenjivim kategorijama prostora i vremena dodaje nova - koja je u neuhvatljivosti jezika i nepouzdanosti pamćenja koje je „bolje od mene“ (Vrkljan, 1966, 140).

Kao temeljno izvorište teksta ,tijelo pamćenja“ je, umjesto instance koja bi jamčila pouzdanost i autentičnost svjedočanstva, nepouzdano, nepredvidljivo, promjenjivo, simultano, sklono ponavljanjima i transgresijama, utjelovljeno, u konačnici - jedan oblik zaborava. No, tako razotkriveno, jedino je dostupno i stoga jedino „istinito“. Kroz prizmu tog „tijela“ prelama se povijest u koju je, kako se vidi u prvom aspektu koji smo istaknule, to tijelo uronjeno: kritika patrijarhalnog odgoja (za strah/srdžbu/ sjećanje), građanskih vrijednosti i morala, nezainteresiranosti za druge, isključivosti, nasilja... Pri tom su osobno i političko povezani motivima probadanja i rezanja - to su bodljikava žica, probodeni leptiri, svila i škare, rezanje pletenica, tekst kao rez - pisanje kao „pitanje protusile, pitanje vlasti“ (Vrkljan, 1984, 31). Odatle pisanje postaje etički obremenjen mehanizam suočavanja s prošlošću, umanjivanja straha od nje, preoznačavanja postojećih predodžbi, uspostavljanja bliskosti i nadoknađivanja izgubljenog, očuvanja sjećanja koja bi prevladana neizrecivošću bila izgubljena, postavljanja pitanja i traganja za mogućim odgovorima. Masa i bezobličnost povezane su sa zalihosnosti jezika, iskustva i emotivnosti, pa se „torture odgoja“ u građanskim sobama i krvava povijest reflektiraju i rastaču u jeziku i između jezika. Pri tom se pisanje/jezik kao vrsta utočišta i refleksije transformira od subverzivne upotrebe vlastite jezične kompetencije (otpor discipliniranju), preko čuvanja i proizvodnje sjećanja do modaliteta za prorađivanje traume. Svaka od ovih uporaba periodično dotiče jezik kao strategiju i prostor mogućnosti i onemogućavanja, vlasti i razvlašćivanja, u nerazlučivosti pjesničkog iskaza i referencijalnosti proznog teksta. 


\section{Zaključak}

Objavljen sredinom 80 -ih i u recepciji prepoznat kao reprezentativan primjer ženskoga pisma, roman Svila, škare djeluje kao ogledni primjer i rodonačelno mjesto autobiografske ,ženske“ proze 80-ih zahvaljujući emancipacijskom potencijalu vlastite narativnosti. Iako od njegovih prvih kritika, preko kasnijih izdanja, do povijesnih i enciklopedijskih prikaza pojam ženskog pisma koji mu je pripisan uvelike funkcionira kao teorijski nerazrađena etiketa dodijeljena prema kriteriju autorstva, ovaj je rad nastojao preoznačiti dosadašnje primjene pojma, nasljedujući s jedne strane njegove teorijske implikacije (Cixous), a s druge ona pitanja koja su ostala neodgovorena i zanemarena od uvođenja pojma u domaći književni kontekst (Šafranek). Svojevrsna po/etika ženskog pisma u romanu Svila, škare vidljiva je najprije u načinu na koji operira žanrovskim i identitarnim konvencijama, istodobno koristeći i opovrgavajući ono što utemeljuje: pisanje ,ženskog života“, autobiografija. Oscilacije između referencijalnog i poetskog/autoreferencijalnog vidljive u započimanju i ostavljanju linearne narativne linije u kojoj ,stati na pola puta znači isto što i ići do kraja“(Vrkljan, 1984, 12) dovode do rastapanja lanca traumatične osobne, obiteljske i opće povijesti - pa i rodne povijesti (povijesti ženskih života) u iskupljujućoj gustoći jezika, igre i stvaralaštva. Žensko pismo bi se stoga i na ovom primjeru trebalo razumjeti kao trajni i nedovršivi proces, kao žensko pisanje koje je najprije u otporu „torturi odgoja“ i nametnutim politikama identiteta, u mogućnosti stvaranja protupriče, a zatim i do kraja - $\mathrm{u}$ dosezljivom prostoru stvaranja, slobode i igre, u jeziku kao stalno obnovljivom izvoru smisla/obesmišljavanja i kreativnosti, onom koje, kako ističe Cixous (2012, 246-247), ostaje u pjesničkom, nesvjesnom, kulturno potisnutom, majci, majčinu mlijeku koje kao „bijela tinta“ ne prestaje teći. Generirajući iz tog izvora mogućnost promjene, transformativnu sposobnost pisanja kao takvog, pa onda i svih mogućih političkih konzekvenca koje ima, žensko pisanje u sebi nosi i pokretačku iskru ,transformacije društvenih i kulturnih struktura“" (Cixous, 2012, 245), utopijski projekt. To je pisanje koje se stvara i razvlašćuje, najavljujući vlastiti dolazak, dolazak žena i života, „san o budućnosti u ženskom rodu“ (Slama, 1983, 99), ono je po sebi avangardno - baš kao što je istaknula Ingrid Šafranek tvrdeći da „mnogi od elemenata koje ćemo prepoznavati kao ženske pripadaju upravo 
pjesničkoj avangardi““ (Šafranek, 1983, 19) te da se u konačnici ne može „lučiti što je tu avangarda, što je specifično žensko“" (Šafranek, 1983, 22), otvarajući tako prostor samom tekstu da se opire interpretaciji, utjelovljenju, ili pamćenju.

\section{Literatura}

Biti, V. (2000). Pojmovnik suvremene književne i kulturne teorije. Zagreb: Matica hrvatska.

Cixous, H. (2012). The Laugh of the Medusa. U: Critical Theory: a Reader for Literary and Cultural Studies. Ur. Robert Dale Parker. New York: Oxford University Press, str. 242-257.

Čale Feldman, L., Tomljenović, A. (2012). Uvod u feminističku književnu kritiku. Zagreb: Leykam International.

Drakulić Ilić, S. (1984). Smrtni grijesi feminizma. Zagreb: Znanje.

Matanović, J., Vrkljan, I. (2004). Pisanje kao odbacivanje bremena. „Sarajevske Sveske“ br. 06/07.

Milanja, C. (1996). Hrvatski roman 1945-1990. Zagreb: Zavod za znanost o književnosti Filozofskog fakulteta Sveučilišta u Zagrebu.

Milanja, C. (2000). Hrvatsko pjesništvo od 1950. do 2000. Zagreb: Zagrebgrafo.

Moi, T. (2007). Seksualna/tekstualna politika. Zagreb: AGM.

Nemec, K. (2003). Povijest hrvatskog romana od 1945. do 2000. Zagreb: Školska knjiga.

Rancière, J. (2008). Politika književnosti. Novi Sad: Adresa.

Slama, B. (1983). Od „ženske književnosti “ do „pisanja u ženskome rodu“. „Republika" vol. 39, str. 85-106.

Stavrakakis, Y. (2012). Challenges of re-politicisation: Mouffe's agonism and artistic practices. „Third Text“ 26, 5, str. 551-565.

Šafranek, I. (1983). „Ženska književnost“ $i$,„žensko pismo “. „Republika“ vol. 39, str. $7-28$.

Visković, V. (1988). Pozicija kritičara: kritičarske opaske o suvremenoj hrvatskoj pro$z i$. Zagreb: Znanje.

Vrkljan, I. (1966). Soba, taj strašan vrt. Beograd: Prosveta.

Vrkljan, I. (1984). Svila, škare. Zagreb: Zora.

Zlatar, A. (2004). Olovka pamćenja. U: Vrkljan, I. Naše ljubavi, naše bolesti. Zagreb: Naklada Ljevak, str. 9-19.

Zlatar, A. (2006). Soba, kuhinja, vlak. U: Vrkljan, I. Sabrana proza 1. Zagreb: Profil, str. 5-29.

Zlatar, A. (2008). Podatni materijal pamćenja. U: Vrkljan, I. Svila nestala, škare ostale. Zagreb: Naklada Ljevak, str. 109-114. 